
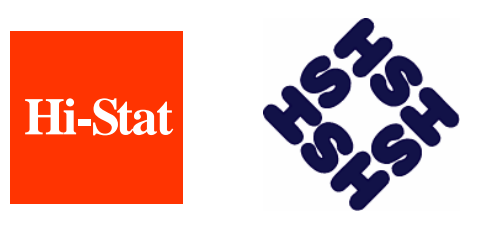

Discussion Paper Series

No.105

The Effectiveness of Bank Recapitalization in Japan

Heather Montgomery and Satoshi Shimizutani

June 2005

Hitotsubashi University Research Unit for Statistical Analysis in Social Sciences A 21st-Century COE Program

Institute of Economic Research Hitotsubashi University Kunitachi, Tokyo, 186-8603 Japan http://hi-stat.ier.hit-u.ac.jp/ 


\title{
The Effectiveness of Bank Recapitalization in Japan"
}

\author{
Heather Montgomery $^{*}$ and Satoshi Shimizutani ${ }^{* *}$
}

This Version: June 2005

\begin{abstract}
:
This study examines the effectiveness of bank recapitalization policies in Japan.

Based on a careful reading of the "business revitalization plan" submitted by banks requesting government funds, we identify four primary goals of the capital injection plan in Japan: 1) to increase the bank capital ratios 2) to increase lending, in particular to small and medium enterprises, and avoid a "credit crunch" 3) to increase write-offs of non-performing loans and 4) to encourage restructuring. Using a panel of individual bank data, we empirically estimate the effectiveness of the Japanese government policy of public fund injection in achieving the first three of these stated goals.

Our empirical analysis of international and domestic banks reveals that the capital injections going to the larger international banks were more effective than those used toward regional banks in Japan. The first capital injection in 1997 was effective primarily in helping international banks to clear the 8\% capital adequacy ratio (BIS ratio) required under the Basel Accord. The second round capital injections seem to have been even more effective, boosting capital adequacy ratios for the regional as well as international banks, and encouraging other policy objectives such as increased lending to small and medium enterprises.
\end{abstract}

\footnotetext{
*The authors thank Yasushi Hamao, Takeo Hoshi, Takatoshi Ito, Akira Kousaka, Randy Kroszner, Colin McKenzie and seminar participants at the NBER Japan Project Meeting (September 2004) and the East Asian Economic Association (November 2004) for their comments on an earlier draft.

${ }_{* * *}^{* *}$ Asian Development Bank Institute Tel: 03-3593-5524 E-mail: hmontgomery@adbi.org

${ }^{* * * *}$ Institute of Economic Research, Hitotsubashi University Tel: 042-580-8369 E-mail: sshimizu@ier.hitu.ac.jp
} 


\section{Introduction}

In recent years, Japanese taxpayers have spent over 10 trillion yen, or $2 \%$ of Japan's nominal GDP, in capital injections into the country's troubled banking sector. More capital injections are likely to come in the near future. Kozo Yamamoto, a member of the LDP's Finance Committee has gone on record stating that if the three-year limit on deferred tax assets, which triggered Resona 's downfall, is applied to other banks, "there will be a flurry" of banks that will need public funds. About half the capital of Japan's big four city banks is made up of DTAs. If this allowance were removed, all would drop below their capital adequacy requirement. Recently, new legislation explicitly allowing "preventive" capital injections will become effective.

Are capital injections effective? Panic and large-scale bank runs have been successfully avoided, but Fukao (2003) has predicted that "the Japanese government will have to nationalize most of the banking sector by 2005. Capital injections will not solve the problems." Indeed, despite over 1 billion yen in capital injections to its predecessors, Daiwa and Asahi, Resona Bank - Japan's $5^{\text {th }}$ largest - had to receive another 2 trillion yen in May 2003, effectively nationalizing the bank. Ashikaga Bank - Japan's $10^{\text {th }}$ largest regional bank - was nationalized in December of that same year despite having already received more than 135 billion in government capital. Another 1 trillion yen was reportedly spent in "stabilizing funds" after nationalization.

There is clear empirical evidence that capitalization affects the behavior of Japanese banks ${ }^{1}$. Montgomery (2004) demonstrates that although both domestic and international banks are insensitive to overall regulatory capital, lending by international banks is highly sensitive to core capital. Ito and Sasaki (2002) shows that banks with lower capital ratios tended to issue more subordinated debts and to reduce lending overall and Peek and Rosengren (1997) have found evidence of the international transmission of negative capital shocks to U.S. loan markets. In later research, Peek and Rosengren (2003) and Watanabe (2004) find evidence that negative shocks to bank capital result in a shift to lower quality loan portfolios.

But despite the large amounts of money at stake, there has been no quantitative research specifically examining the effectiveness of capital injections. This study aims to inform the policy debate on how best to deal with systemic weakness in the banking sector. Thus, this study holds important policy implications, not only for Japan, but also for other countries facing similar banking sector problems. In the wake of the Asian Crisis of 1997, governments throughout have been allocating huge amounts of public funds to bail out the troubled financial sectors in those countries.

Based on a careful reading of the "business revitalization plan" submitted by banks requesting government funds, we identify four primary goals of the capital injection plan in Japan: 1) to increase the bank capital ratios 2) to increase lending, in particular to small and medium enterprises, and avoid a "credit crunch" 3 ) to increase

\footnotetext{
${ }^{1}$ In addition to the studies cited above, readers may see the following related papers: Baba (1995), Honda (2002), Horiuchi, and Shimizu (1998), Ueda (1993) and Yoshikawa and Ike (1994).
} 
write-offs of non-performing loans and 4) to encourage bank restructuring. Using a panel of individual bank data, we empirically estimate the effectiveness of the Japanese government policy of public fund injection in achieving the first three of these stated goals.

This paper is organized as follows: section II briefly outlines the most recent history of Japan's banking sector crisis and section III catalogues the policy response, focusing on the government's decision to inject public funds into the banking sector. Section IV explains the mechanisms by which capital injections may influence bank behavior. Section V describes the data and empirical specification as well as the results of our regression analysis. Section V concludes.

\section{Japan's Banking Sector in Crisis}

Although warning signs had been evident much earlier ${ }^{2}$, the weakness in the Japanese financial sector reached a crisis in 1997. The first to fall was Sanyo Securities, a midsized securities company that folded on November 3, 1997. The next failure was even larger. Hokkaido Takushoku Bank failed on November 17, $1997^{3}$, costing the DIC $3,411.3$ billion yen, more than the 2,514 billion yen that had been used in all the DIC's previous history. One week later, on November 24, 1997, Yamaichi Securities, one of Japan's oldest and largest brokerage firms, followed suit. Only 2 days later, Tokuyo City Bank, a small regional bank, collapsed on November 26, 1997.

The following year, two other "top 20" banks were nationalized. The Long-Term Credit Bank of Japan was placed under state stewardship on October 23, 1998 and Nippon Credit Bank followed on December 13 of the same year. The DIC acquired all outstanding shares of both banks and provided credit to them to continue operating ${ }^{4}$.

All of these institutions had previously been considered "too big to close". The three banks were ranked among the nations "top 20" banks, which dominated the lending markets, and Yamaichi was one of the top 4 securities houses, which had previously accounted for over $70 \%$ of the securities business. These failures marked the end of the traditional "convoy system" safety net. The news led to a sell off of bank shares on the stock market and the emergence of the so-called "Japan Premium" in overseas lending markets

\footnotetext{
${ }^{2}$ Several small financial institutions failed between 1992 and 1997 and by the end of 1997, sixteen credit cooperatives, shinkin banks, and regional banks had failed and mergers had been arranged with healthier institutions under the so-called "convoy system". Then, in October 1995 it was reported that all 7 of Japan's jusen (home mortgage companies) were completely insolvent. Under a controversial resolution scheme, these losses were also largely passed on to large financial institutions.

${ }^{3}$ Actual grant and asset purchase by the DIC took place in October of 1998.

${ }^{4}$ Actual grant and asset purchase by the DIC took place in August and October of 1999. LTCB was later re-privatized as Shinsei Bank and NCB as Aozora Bank.
} 


\section{Policy Response: 1998-1999}

In February 1998 the Diet responded to the financial crisis with the Financial Function Stabilization Plan ${ }^{5}$, which allocated 30 trillion yen to the Deposit Insurance Corporation: 17 trillion yen for a Special Operations Account, which was to supplement the already established General Account in order to provide full deposit protection of insolvent banks, and 13 trillion yen to a newly established Financial Crisis Management Account.

The Financial Crisis Management Account funds went toward a capital injection of all 19 of the top city, trust and long-term credit banks at the close of fiscal year 1997 (March 1998). In total, 1.8 trillion in capital was given out in the form of purchases of preferred stock, subordinated debt, or as a subordinated loan (See table 1 for details). Many banks were reluctant to apply for the funds for fear of the message it would send to the market, so all banks were pressured to apply for the same amount of capital. Even TokyoMitsubishi bank, which did not wish to apply for a capital injection, was pressured to apply for the standard 100 billion yen ${ }^{6}$. Regional banks - Yokohama Bank, Ashikaga Bank and Hokuriku Bank - applied for smaller capital injections. Since subordinated debt, subordinated loans and preferred stock count toward Tier II $^{7}$ capital in calculating the capital to risk weighted asset ratio reported to the Bank for International Settlements, this helped many banks clear the $8 \%$ capital to risk weighted asset ratio required under the Basel Accord.

Even with the capital injection, many banks faced difficulty in meeting the 8\% capital requirement, so authorities also implemented several other changes. Accounting standards were relaxed in fiscal year 1997 in order to boost the banks' reported capital ${ }^{8}$. In April 1998, the start of fiscal year 1998, the "Law to Ensure the Soundness of Financial Institutions ${ }^{9 "}$ - equivalent to the Prompt Corrective Action (PCA) measures in force in the United States since the late 1980s - were introduced. In June 1998, the Financial Supervisory Agency (FSA) was established. The FSA took over the supervision of banks, securities firms and insurance companies from the Ministry of Finance. The

\footnotetext{
${ }^{5}$ This included two laws to stabilize the financial system, including the Financial Function Stabilization Law.

${ }^{6}$ Tokyo-Mitsubishi is the only bank to have repaid the public funds in full.

${ }^{7}$ Dated (more than 5 years) subordinated debt, subordinated loans and preferred stock count as Tier II capital. Perpetual preferred stock and subordinated debt count as Tier I capital. In recent years, some short term (more than 2 years but less than 5 years) subordinated debt has been counted as Tier III capital.

${ }^{8}$ Banks were given the option of using either fair value accounting, the lower of book or market value method, or book value. This meant that banks did not necessarily have to report losses on securities held in their trading account on their balance sheets. Secondly, banks were allowed to count $45 \%$ of revalued land holdings toward Tier II capital. Although land prices were substantially lower than during the bubble period, most land held on the banks' balance sheets still carried a market value much higher than the historical cost.

${ }^{9}$ This law has two main components. First, the law defines a self-assessment process whereby banks value assets themselves according to well-defined guidelines. These findings are subject to review by external auditors and bank examiners. These new "risk asset" categories are broader than the non-performing loan categories used by the Japanese Bankers Association since 1993 (see appendix for details). Secondly, the law specifies capital thresholds under which regulators can order banks to take remedial action ranging from a forced reduction in the number of branches to liquidation.
} 
FSA also took over the supervision of shinkin banks from the Regional Financial Bureaus and the supervision of credit cooperatives from the prefectural governments. In the Fall of 1998 the FSA conducted full-scale on-site bank examinations of all the major banks. The Agency concluded that the self-assessment of asset quality undertaken by the banks in March 1998 were based on overly optimistic assumptions and that both the major banks and regional banks had significantly understated their non-performing loans.

In response to these findings, in October 1998, after months of deliberation in a special "Financial Diet Session", the Diet approved another plan to deal with the problems in the banking sector. The Financial Revitalization Plan ${ }^{10 i}$ doubled the amount of funds allocated to dealing with the crisis to 60 trillion yen. The 60 trillion was earmarked for three separate accounts within the DIC. The Special Operations Account, which was to supplement the already established General Account in order to provide full deposit protection of insolvent banks, received 17 trillion of the 60 trillion total. The Financial Reconstruction Account, which received 18 trillion yen, was to be used for the purchase and collection of assets in liquidating or nationalizing insolvent banks. As reported in figure 21 , about $1 / 3$ of the funds in this account have been used to date. Finally, the Early Strengthening Account replaced the Financial Crisis Management Account. The Early Strengthening Account, to be used in recapitalizing weak but solvent banks, received the largest endowment of 25 trillion yen.

The early strengthening account funds were used in a second round of capital injections in March of 1999 (the close of fiscal year 1998). 14 of the largest city, long term credit and trust banks, as well as Yokohama Bank received a total of 7.5 Trillion Yen (\$75 Billion), 4 times that of the first capital injection in March of 1998. As in 1998, the capital injection took the form of purchases by the DIC of preferred shares or subordinated debts or loans issued by the banks. Unlike the capital injection of 1998, the amount of the capital injection varied by bank and reflected the conditions of individual banks. To qualify for the capital injection, the FRC required each bank to submit a restructuring plan, including raising new capital from the private sector, which would be subject to quarterly review ${ }^{11}$.

In addition to the capital injections, regulations on consolidated balance sheet reporting were tightened in December 1998. Prior to that time, banks were required to consolidate in their financial reporting only those subsidiaries and affiliates in which they had more than a 50 percent stake and a 20 percent stake respectively. Under the new law, subsidiaries of banks and any company of which the bank group (a keiretsu with which the bank is associated) has more than a 40 percent stake have to consolidated in the

\footnotetext{
${ }^{10}$ The Financial Revitalization Plan included 4 new laws, two of which were the "Financial Function Reconstruction Law" and the "Early Strengthening Law". The "Financial Function Reconstruction Law" is officially called the Law Concerning Emergency Measures for the Reconstruction of the Function of the Financial System and the "Early Strengthening Law" is officially called the Law Concerning Emergency Measures for the Early Strengthening of the Financial Function.

${ }^{11}$ If not satisfied, the FSA could convert its holdings of preferred stocks to common stocks after a certain grace period, the length of which is determined by the strength of the bank, and as largest shareholder could put pressure on management. The Bank of Tokyo Mitsubishi did not apply for capital injection and instead made public its intention to pay off the subordinated debt issued to the government in March 1998.
} 
financial reporting of the banks on a line by line basis. Thus, affiliation was more determined by influence than just strictly share holdings. Banks affiliates and any company of which a bank or bank group has more than a 15 percent stake and whose decisions are controlled by the bank were required to consolidate using the "equity method" (not line by line). Consolidated reporting requirements applied to nonperforming loan estimates as well. Prior to December 1998 banks had been able to use "related companies" to clean up their balance sheets. Banks could set up related companies which were neither subsidiaries nor affiliates, and transfer their nonperforming loans to these related companies at above market value. These related companies were jointly owned by the banks (who owned less than $5 \%$ each) and the firms in the banks keiretsu with whom the bank also had interlocking shares.

Tightening of financial regulation continued in fiscal year 1999. In April 1999 the FSA extended the Prompt Corrective Action (PCA) framework to purely domestic banks without international operations. The FSA then conducted an inspection of regional banks in the Fall of 1999. As a result of this inspection, the FSA recommended the merger of Hanshin Bank and Midori Bank into Minato Bank. Four other regional banks -Namihaya, Kofuku, Kokumin and Tokyo Sowa -- were found to be insolvent. They were be operated by public administrators as a bridge bank until successor institutions were found. Two other regional banks, Niigata-Chuo Bank ${ }^{12}$ and Hokkaido Bank, were ordered to increase their capital in order to meet the $4 \%$ capital adequacy requirement.

Finally, mark-to-market accounting on all securities, including investment account securities, will be required as of fiscal year 2001. This will force banks to realize any hidden gains or losses on the equities held on their balance sheets and probably give banks incentives to sell off unprofitable investments rather than keep the shares as a way to cement business ties. To assist banks in this transition, the government is establishing an entity to purchase stocks held by the banks.

The most recent trend in the Japanese Banking Sector has been consolidation. The old "top 20" banks have been consolidated into 4 large groups: the Mizuho Financial Group, Sumitomo-Mitsui Financial Group, Tokyo-Mitsubishi Financial Group and UFJ Group ${ }^{\text {ii }}$.

\section{Capital Injections and Bank Behavior}

Although bank managers may care about capital ratios for various reasons, capital ratios affect bank behavior primarily because of regulation. Japanese banks face different regulations on capital depending upon whether they are internationally active or a purely domestic bank.

\footnotetext{
${ }^{12}$ Niigata-Chuo Bank later failed. See appendix for details.
} 


\section{International Banks}

International banks are required to maintain a capital to risk-weighted asset ratio of at least $8 \%$. This ratio is required not only of Japanese banks, but under the Basle Accord of 1998, of most internationally active banks worldwide.

$$
B I S=\frac{\text { TierI }+ \text { TierII }+ \text { TierIII }- \text { Goodwill }}{R W A}
$$

Tier 1, or Core Capital is basically shareholder's equity, with some adjustment for goodwill. Tier 1 Capital includes perpetual preferred stock.

Tier 2 Capital in Japan includes up to $45 \%$ of the latent capital gains banks hold on equities, $45 \%$ of any revaluation of land held on their books ${ }^{\mathrm{iii}}$, up to $1.25 \%$ of General Loan Loss Provisions, Dated Preferred Stock and Dated Subordinated Debt dated at more than 5 years. Dated Preferred Stock and Subordinated Debt are counted at full value up to $50 \%$ of the value of Tier 1 capital.

Tier 3 Capital includes short-term (more than 2 years but less than 5 years) subordinated debt.

Risk Weighted Assets (RWA) are calculated as a weighted sum of assets held by the bank. "Riskless" assets such as government bonds, receive a $0 \%$ weighting, while "risky" assets such as loans, corporate bonds and equities receive a 100\% weighting. Mortgages and local government bonds fall in between.

\section{Domestic Banks}

Domestic banks in Japan face a more lenient requirement of a 4\% "MOF" (Ministry of Finance) ratio.

$$
M O F=\frac{\text { TierI }+\operatorname{TierII}(M O F)-\text { Goodwill }}{R W A(M O F)}
$$

Most components of the MOF ratio are calculated similarly to the BIS ratio for international banks, but Tier 2 Capital does not include latent capital gains on securities and short-term subordinated debt is not counted as Tier 3 capital.

In order to meet the capital adequacy requirements discussed above, banks can either adjust risk-weighted assets (the denominator) or capital (the numerator). It is generally easier and less costly for banks to adjust their risk-weighted assets. Thus, capital constrained banks may be inclined to substitute out of heavily weighted "risky" assets such as loans and equities into lower weighted assets such as government bonds. Or conversely, banks receiving a capital injection from the government may be inclined to shift their portfolios by shifting out of government bonds into loans.

\section{Empirical Analysis}

This section presents an empirical analysis of the effectiveness of the capital injections made to banks in fiscal year 1997 and 1998. 


\section{Data}

A panel of data from 106 banks' balance sheets and income statements for fiscal years $1990-1999^{13}$ is used to estimate the effectiveness of the capital injections. Regional and International Banks are analyzed separately to preserve the homogeneity of the sample.

Several banks are excluded from the analysis due to nationalization, failure, or because they were established mid-sample (see appendix 1 for details). Mergers are accounted for by treating the merged bank as one entity for the entire sample period. Loans (kashidashikin goukei) are the sum of domestic loans to all industries plus international loans and trust account loans as reported in the annual yukashoken hokokusho reports.

We use three different measures of capital strength in the empirical analysis: the official regulatory capital ratio (the MOF ratio for domestic banks and BIS ratio for internationally active banks: jikoshihon hiritsu), the ratio of capital as reported on the balance sheet (shihon) to total assets (shisan) and the ratio of "core" Tier I capital to total assets.

Non-performing loans are measured using the Japanese Bankers Association definition (see appendix 2 for a detailed description of the various measures of nonperforming assets), loans to bankrupt borrowers (hatansaki). This category is the strictest definition of non-performing loans and thus underestimates total non-performing assets, but we select it since it is the only measure of non-performing loans that has been reported by all banks since reporting was required in 1993 and the definition of this category of loans has not changed substantially as is the case for other classes of bad assets.

Written-off bad debt is defined as only direct write-offs (kashidashikin kyuufukin shoukyaku). Direct write-offs include only non-performing assets that are completely removed from the balance sheet by either write-off or selling the loan at a loss to the CCPC (Cooperative Credit Purchasing Company). Indirect write-offs, which also include transfers of funds to the allowance for loan losses on the banks' balance sheets, largely determined by the Financial Services Agency (FSA) "self assessment of asset quality" but also are to some extent dictated by past performance.

Our measure of profits is operating profits (keijyorieki). In order to cover bad debt write-offs, banks have taken large hits to their post-provision operating profits ${ }^{14}$. All the major banks have reported negative post-provision operating profits every year since fiscal year 1994. They have been able to compensate for this to some extent by

\footnotetext{
${ }^{13}$ Although longer time series data is available, the sharp consolidation of Japan's banking sector described above means that a consistent panel of data is not available after 2000.

${ }^{14}$ Post-provision operating profits include deductions for other kinds of provisioning as well, such as writedown of sovereign risk loans or transfers to reserve for other credit losses, but these figures are much smaller than the sum of transfer to reserve for loan losses, loan charge-offs and losses on sales of loans to the CCPC.
} 
selling off equity holdings (realizing their latent gains on equities), allowing them to report positive pre-tax profits ${ }^{15}$ in some years. However, operating profits, which are calculated before provisions, write-offs, latent capital gains realizations and taxes, are the best measure of a banks current performance.

National and regional (prefectural) GDP are included to control for the national and regional business cycle.

With the exception of the BIS ratios, balance sheet data is reported at book value and on an unconsolidated basis. In fiscal year 1997 many large banks began reporting on a consolidated basis and all banks are now required to do so, but unconsolidated data is used in order to construct a continuous time series. GDP data is reported at current prices. Data was compiled from the Nikkei Needs Company data set, Bureau Van Dijk Electoronic Publishing Bankscope data set and publicly available data on national GDP, prefectural level GDP and the amount of capital injections.

\section{Empirical Specification}

We investigate the effect of the capital injections on four dependent variables: the regulatory capital ratio ${ }^{16}$ (the BIS or MOF ratio), growth in total lending, growth in lending to small and medium enterprises, and loan write-offs (change as a ratio to total assets) with the following specification (equation 1):

$$
Y_{i, t}=\alpha+\beta X_{i, t-1}+\gamma Z_{i, t-1}+\varepsilon_{i, t}
$$

where $Y_{i, t}$ represents the dependent variable: growth in total lending, growth in lending to small and medium enterprises and the regulatory capital ratio in time $t$ for bank i. Vector $X_{i, t-1}$ denotes bank specific factors that influence loan growth such as GDP growth (regional GDP for the regional banks), change in operating profits to total assets and change in bad loan write offs to total assets. Vector $Z_{i, t-1}$ comprises variables that indicate a bank's capital position, including the amount of capital injection. As indicated in equation 1, to address possible endogeneity between the dependent variable and the banks' capital position or other bank-specific factors, we use lagged variables as instruments. We report the results using a random effects model, as supported by Hausman specification test results ${ }^{17}$.

\footnotetext{
${ }^{15}$ Pre-tax profits are also adjusted for profits and losses on investments in trusts, write--downs of equity securities and profits and losses on disposal of fixed assets, but these items are much smaller than the profits on sales of equity securities.

${ }^{16}$ The regulatory capital ratio specification is estimated using Arellano and Bond's (1991) Generalized Method of Moments estimator since in some regressions we use lagged regulatory capital (the dependent variable) as a predetermined variable on the right hand side.

${ }^{17}$ For most of the empirical specifications, the Hausman test failed to reject the null hypothesis that the random effects model specification was efficient. As a robustness check, we looked at both random and fixed effect specifications but failed to find any significant qualitative or quantitative difference in the results from the two models.
} 
We use three different measures of overall capital strength: capital to total assets, regulatory capital to risk-weighted assets and "core" tier I capital to total assets. To look specifically at the effect of the capital injections, we interact these measures of capital strength with a dummy for banks and years in which capital was injected. We also do a separate estimation including the actual amount of capital injected as a percentage of the banks' total assets.

As described in section III, the capital injection of 1997 and 1998 were handled quite differently, and thus may well have had different effects on bank behavior. Ito and Harada (2004) find aggregate evidence of this in their note on the disappearance of the Japan premium in March 1999. To investigate the hypothesis that the capital injections of 1997 and 1998 had differential impact, we look at the two injections separately in our regression analysis ${ }^{18}$.

\section{$\underline{\text { Results }}$}

\section{International Banks}

Estimation results for international banks are reported in tables 3-6. Looking at table 3, we see that overall regulatory capital was higher for those banks that received a capital injection in both 1997 and 1998. Regulatory capital is also sensitive to the amount of capital received - those banks that received more injected capital (as a percentage of the bank's assets) had higher regulatory capital ratios in the following period. Coefficient estimates are highly significant for both rounds of the capital injection, but slightly larger for the first capital injection in 1997, perhaps because the primary goal of the 1997 injection was to help internationally active banks clear the $8 \%$ capital adequacy ratio (BIS ratio) required under the Basel Accord.

The capital injection of 1997 also seems to have encouraged international banks to write-off bad loans (table 4). Bad loan write-offs for international banks are sensitive to both receipt of capital and the amount of capital injected for the first round capital injection, but not for the second round.

Despite much public discussion, the capital injections seem to have done little to counteract or prevent a possible credit crunch. The second round capital injection in 1998 seems to have had no effect on total loan growth and the first round capital injection in 1997 in fact seems to have reduced loan growth (table 5). Although total loan growth is sensitive to various measures of the banks' capitalization, for the first round of injections, total loan growth was actually lower for those banks that received capital and the growth in total lending was negatively related to the amount of capital the banks received.

Looking in particular at lending to small and medium enterprises (table 6), note that in 1998, lending was higher for banks that received a capital injection and was

\footnotetext{
${ }^{18}$ The authors thank participants at the NBER Japan Project Meetings in Tokyo September 2004, in particular Takatoshi Ito and Takeo Hoshi, for this suggestion.
} 
sensitive to the amount of capital injected. In 1997, however, we again find a negative correlation between receipt of a capital injection and loans to SMEs. For the first round capital injection, banks that received a capital injection tended to do less lending to SMEs and the amount of SME lending was negatively correlated with the amount of capital received. This may in part be explained by the negative relationship between capitalization levels and SME lending - it appears that on average banks that are less well capitalized tend to do more lending to SMEs.

In summary, the first round of the capital injection in fiscal year 1997 seems to have been used primarily to help international banks to clear the BIS standard. The negative effect we find of the 1997 capital injection on total lending and SME lending in particular, may be explained by this pressure on international banks to clear the BIS standard, resulting in a "capital crunch" as banks reduced heavily risk-weighted assets such as loans. Once banks cleared the BIS standard in 1997, they seem to have been able to address concerns about a credit crunch. Although the second round of capital injections in fiscal year 1998 also raised regulatory capital ratios, in addition it stimulated banks to increase lending to SMEs.

\section{Regional Banks}

The effect of the injections on regulatory capital for the regional banks, reported in tables 7-9, is quite different than what we found earlier for the international banks.

As was the case with the international banks, regulatory capital ratios for the regional banks (the domestic MOF ratio set by the ministry of finance) were boosted by the second round capital injection: regional banks' capital ratios were sensitive to both receipt of a capital injection and the amount of capital injected (table 7). For the first round of capital injections in fiscal year 1997, however, we find that an inverse relationship holds - those banks that received a capital injection tended to have lower capital ratios in the following period and this tendency was stronger the more capital the banks received.

Bad loan write-offs for the regional banks also show an inverse relationship with with amount of capital injected in the first round in 1997 - banks that got relatively more capital wrote off relatively less bad debt (table 8). For the second round capital injection there is no statistically significant relationship between either reciept of capital or the amount of capital injected and bad loan write-offs. Overall, bad loan write-offs are also unaffected by the banks' capital ratios as well.

Lending by the regional banks, both in total and to SMEs, shows no sensitivity to either receipt of a capital injection or to the amount of capital injected in either year (table 8 and 9).

In summary, the first round of the capital injection in FY1997 had a negative effect on regulatory capital ratios and bad loan write-offs for regional banks while the second round helped them to enhance the capital ratio. Both rounds of injections had little effect on lending by the regional banks. 


\section{$\underline{\text { V. Conclusions }}$}

Our findings show that the second round of capital injections (in 1998 for international banks and 1999 for regional banks) was more effective than the first capital injection in 1997. This result holds for both international and domestic banks, although we find that the capital injections were had generally more impact on the behavior of international banks than domestic banks.

The first round of capital injections in 1997 does seem to have raised regulatory capital ratios for international banks (the BIS ratio), but for regional banks regulatory capital was actually lower for those banks that received relatively more capital. Write-off of bad debt by the regional banks were also negatively related to the amount of capital injected during the first round, while loan growth - both on aggregate and to SMEs in particular - seems to have been unaffected.

The second round of injections, on the other hand, were effective in raising capital ratios for the international banks and this increase was sensitive to the amount of capital the banks' received. Although overall loan growth was still unaffected during the second round, this later round of injections enabled international banks to increase lending to SMEs, which were of particular concern to policy makers at the time.

This first round capital injection was uniformly handed out regardless of the condition of the recipient banks and the banks' proposed use of the injected capital, which is why it seems to have had little effect other than a "band-aid" to keep troubled banks above the required minimum regulatory capital ratio. The amount of capital administered during the second round, however, was much larger and varied by bank to reflect conditions at the individual banks. To qualify, banks were required to submit a restructuring plan that outlined how the capital would be used. This approach seems to have been more effective in achieving policy objectives. 


\section{References}

Baba, N., 1995. Kinnen no ginko kashidashi no teimei ni kansuru jissho bunseki. Mimeo. Institute of Monetary and Economic Studies, Bank of Japan.

Fukao (2003) "Financial Sector Profitability and Double-Gearing" in Structural Impediments to Growth in Japan Blomstrom, Magnus, Jennifer Corbett, Fumio Hayashi, and Anil Kashyap, editors. University of Chicago Press.

Honda, Y., 2002. The effects of the Basel Accord on bank credit: the case of Japan. Appl. Econ. 34, 1233-1239.

Horiuchi, A., Shimizu, K., 1998. The deterioration of bank balance sheets in Japan: risk taking and recapitalization. Pacific-Basin Finance J. 6, 1-26.

Hoshi, T. 2001. What happened to Japanese Banks? . Bank of Japan's Monetary and Economic Studies, February: 1-29.

Ito, T., Harada, K, 2004. Credit Derivatives as a New Japan Premium. The Journal of Money, Credit and Banking Vol. 36, No. 5. (Oct., 2004), pp. 965-968. (The Ohio State University Press).

Ito, T., Sasaki, Y., 2002. Impacts of the Basel Capital Standard on Japanese banks' behavior. J. Japanese Int.Economies 16, 372-397.

Kroszner, R. and Rajan, R., 1994. Is the Glass-Steagall Act Justified? A Study of the U.S. Experience with Universal Banking before 1933. American Economic Review 84$4,810-832$.

Montgomery, H. 2005. The effect of the Basel Accord on bank portfolios in Japan. J. Japanese Int. Economies 19, 24-36.

Peek, J., Rosengren, E., 1997. The international transmission of financial shocks: the case of Japan. Amer. Econ. Rev. 87-4, 495-505.

Peek, J., Rosengren, E., 2003. Unnatural selection: Perverse incentives and the misallocation of credit in Japan. NBER working paper 9643.

Ueda, K., 1993. Heisei fukyo wo koete. Seisaku Koso Forum report. Tokyo.

Watanabe, W. 2004. Do negative shocks to bank capital cause flight to quality? : evidence from the Japanese financial crisis. Unpublished mimeo, Osaka University.

Yoshikawa, H., Ike, T., 1994. Chusho kigyo ni taisuru ginkou ni yoru kashishiburi ni tsuite keizai-bunseki: seisaku kenkyu no shiten. Working paper 1. Economic Planning Agency, Tokyo. 
Table 1: Details on Capital Injections

1997 - International Banks

\begin{tabular}{|c|c|c|c|}
\hline Bank Name & $\begin{array}{c}\text { Amount of Capital Injection } \\
\text { (billion Yen) }\end{array}$ & $\begin{array}{l}\text {...of which } \\
\text { Tier I }\end{array}$ & $\begin{array}{c}\text {...of which } \\
\text { Tier II }\end{array}$ \\
\hline Asahi & 100 & & 100 \\
\hline Daiichi Kangyo & 99 & 99 & \\
\hline Daiwa & 100 & & 100 \\
\hline Fuji & 100 & & 100 \\
\hline Industrial Bank of Japan & 100 & & 100 \\
\hline Mitsui Trust & 100 & & 100 \\
\hline Sakura & 100 & & 100 \\
\hline Sanwa & 100 & & 100 \\
\hline Tokai & 100 & & 100 \\
\hline Tokyo Mitsubishi & 100 & & 100 \\
\hline Toyo Trust & 50 & & 50 \\
\hline Yasuda Trust & 150 & & 150 \\
\hline \multicolumn{4}{|l|}{1997 - Regional Banks } \\
\hline Bank Name & $\begin{array}{l}\text { Amount of Capital Injection } \\
\text { (billion Yen) }\end{array}$ & $\begin{array}{c}\text {...of which } \\
\text { Tier I }\end{array}$ & $\begin{array}{c}\text {...of which } \\
\text { Tier II }\end{array}$ \\
\hline Ashikaga & 30 & & 30 \\
\hline Hokkaido & 45 & & 45 \\
\hline Hokuriku & 20 & & 20 \\
\hline \multicolumn{4}{|c|}{1998 - International Banks } \\
\hline Bank Name & $\begin{array}{l}\text { Amount of Capital Injection } \\
\text { (billion Yen) }\end{array}$ & $\begin{array}{c}\text {...of which } \\
\text { Tier I }\end{array}$ & $\begin{array}{c}\text {...of which } \\
\text { Tier II }\end{array}$ \\
\hline Asahi & 500 & 400 & 100 \\
\hline Daiichi Kangyo & 900 & 700 & 200 \\
\hline Daiwa & 408 & 408 & \\
\hline Fuji & 1000 & 800 & 200 \\
\hline Industrial Bank of Japan & 600 & 350 & 250 \\
\hline Mitsubishi Trust & 300 & 200 & 100 \\
\hline Mitsui Trust & 400.2 & 250.2 & 150 \\
\hline Sakura & 800 & 800 & \\
\hline Sanwa & 700 & 600 & 100 \\
\hline Sumitomo Trust & 300 & 100 & 200 \\
\hline Tokai & 600 & 600 & \\
\hline Toyo Trust & 200 & 200 & \\
\hline \multicolumn{4}{|l|}{1999 - Regional Banks } \\
\hline Bank Name & $\begin{array}{c}\text { Amount of Capital Injection } \\
\text { (billion Yen) }\end{array}$ & $\begin{array}{c}\text {...of which } \\
\text { Tier I }\end{array}$ & $\begin{array}{c}\text {...of which } \\
\text { Tier II }\end{array}$ \\
\hline Ashikaga & 105 & 105 & \\
\hline Bank of the Ryukyus & 40 & & 40 \\
\hline Hiroshima Sogo & 40 & 20 & 20 \\
\hline Hokuriku & 75 & 75 & \\
\hline Kumamoto Family & 30 & 30 & \\
\hline
\end{tabular}


Table 2: Summary Statistics

\begin{tabular}{|c|c|c|c|c|c|}
\hline Variable & \# Obs & Mean & Std. Dev. & Min & Max \\
\hline $\begin{array}{l}\% \text { Growth } \\
\text { Total Loans }\end{array}$ & 1258 & 1.55 & 7.49 & -23.52 & 122.75 \\
\hline $\begin{array}{l}\text { \% Growth } \\
\text { SME Loans }\end{array}$ & 1254 & 1.15 & 16.02 & -83.35 & 89.27 \\
\hline $\begin{array}{l}\% \text { Growth } \\
\text { Bad Loan } \\
\text { Write Offs } \\
\text { (as \% assets) }\end{array}$ & 1195 & 0.01 & 0.21 & -1.79 & 2.12 \\
\hline $\begin{array}{l}\% \text { Growth } \\
\text { Profits } \\
\text { (as \% assets) }\end{array}$ & 1258 & -0.05 & 0.90 & -13.16 & 7.49 \\
\hline $\begin{array}{l}\text { \% Growth } \\
\text { GDP }\end{array}$ & 1168 & 1.07 & 2.42 & -6.39 & 8.89 \\
\hline $\begin{array}{l}\text { BIS or MOF } \\
\text { Regulatory Capital } \\
\text { Ratio }\end{array}$ & 1359 & 8.54 & 2.22 & 0.4 & 15.4 \\
\hline $\begin{array}{l}\text { Capital } \\
\text { (as \% assets) }\end{array}$ & 1364 & 4.06 & 1.03 & 0.13 & 8.55 \\
\hline $\begin{array}{l}\text { Core } \\
\text { Capital } \\
\text { (as \% assets) }\end{array}$ & 654 & 4.19 & .81 & 2.60 & 9.00 \\
\hline $\begin{array}{l}\text { Capital } \\
\text { Injection } \\
\text { (as 1000th \% assets) }\end{array}$ & 1364 & 0.03 & .25 & 0 & 4.24 \\
\hline $\begin{array}{l}\text { Real Estate } \\
\text { Lending } \\
\text { (as \% domestic loans) }\end{array}$ & 1269 & 7.27 & 3.01 & 1.62 & 17.41 \\
\hline
\end{tabular}


Table 3 International Banks

Panel Estimates (Random Effects Model)

\begin{tabular}{|c|c|c|c|c|c|c|}
\hline $\begin{array}{l}\text { Dependent Variable: } \\
\text { BIS Capital Ratio }\end{array}$ & 1 & 2 & 3 & 4 & 5 & 6 \\
\hline Profit(t-1), \% change & $\begin{array}{l}0.262 \\
{[0.062] * * *}\end{array}$ & $\begin{array}{l}0.125 \\
{[0.059]^{* *}}\end{array}$ & $\begin{array}{l}0.3 \\
{[0.105] * * *}\end{array}$ & $\begin{array}{l}0.197 \\
{[0.078]^{* *}}\end{array}$ & $\begin{array}{l}0.106 \\
{[0.073]}\end{array}$ & $\begin{array}{l}0.298 \\
{[0.131]^{* *}}\end{array}$ \\
\hline GDP(t-1), \% change & $\begin{array}{l}0.302 \\
{[0.090]^{* * * *}}\end{array}$ & $\begin{array}{l}0.2 \\
{[0.093]^{* *}}\end{array}$ & $\begin{array}{l}0.032 \\
{[0.091]}\end{array}$ & $\begin{array}{l}0.202 \\
{[0.108]^{*}}\end{array}$ & $\begin{array}{l}0.126 \\
{[0.108]}\end{array}$ & $\begin{array}{l}-0.013 \\
{[0.107]}\end{array}$ \\
\hline $\begin{array}{l}\text { Bad Loans }(t-1), \\
\% \text { change }\end{array}$ & $\begin{array}{l}0.0014 \\
{[0.00148]}\end{array}$ & $\begin{array}{l}0.00182 \\
{[0.00163]}\end{array}$ & $\begin{array}{l}0.0009 \\
{[0.00147]}\end{array}$ & $\begin{array}{l}0.00134 \\
{[0.00183]}\end{array}$ & $\begin{array}{l}0.00182 \\
{[0.00189]}\end{array}$ & $\begin{array}{l}0.00125 \\
{[0.00180]}\end{array}$ \\
\hline $\begin{array}{l}\text { Capital Injection } \\
\text { Dummy97(t-1) }\end{array}$ & $\begin{array}{l}2.547 \\
{[0.308] * * *}\end{array}$ & $\begin{array}{l}3.138 \\
{[0.345] * * *}\end{array}$ & $\begin{array}{l}3.094 \\
{[0.308]^{* * *}}\end{array}$ & & & \\
\hline $\begin{array}{l}\text { Capital Injection } \\
\text { Dummy98(t-1) }\end{array}$ & $\begin{array}{l}1.725 \\
{[0.502]^{* * *}}\end{array}$ & $\begin{array}{l}2.955 \\
{[0.484] * * *}\end{array}$ & $\begin{array}{l}2.388 \\
{[0.448] * * *}\end{array}$ & & & \\
\hline $\begin{array}{l}\text { Capital Injection97 } \\
\text { /Bank Assets(t-1) }\end{array}$ & & & & $\begin{array}{l}2.576 \\
{[0.628]^{* * * *}}\end{array}$ & $\begin{array}{l}3.454 \\
{[0.583]^{* * *}}\end{array}$ & $\begin{array}{l}3.398 \\
{[0.545]^{* * *}}\end{array}$ \\
\hline $\begin{array}{l}\text { Capital Injection98 } \\
\text { /Bank Assets(t-1) }\end{array}$ & & & & $\begin{array}{l}0.804 \\
{[0.303] * * *}\end{array}$ & $\begin{array}{l}1.289 \\
{[0.249]^{* * *}}\end{array}$ & $\begin{array}{l}1.057 \\
{[0.244]^{* * *}}\end{array}$ \\
\hline $\begin{array}{l}\text { BIS/MOF } \\
\text { Capital Ratio(t-1) }\end{array}$ & $\begin{array}{l}0.72 \\
{[0.118] * * *}\end{array}$ & & & $\begin{array}{l}0.482 \\
{[0.180]^{* * *}}\end{array}$ & & \\
\hline $\begin{array}{l}\text { Total Capital / } \\
\text { Asset Ratio(t-1) }\end{array}$ & & $\begin{array}{l}0.322 \\
{[0.119]^{* * *}}\end{array}$ & & & $\begin{array}{l}0.086 \\
{[0.120]}\end{array}$ & \\
\hline $\begin{array}{l}\text { Core Capital } \\
\text { Ratio(t-1) }\end{array}$ & & & $\begin{array}{l}0.567 \\
{[0.100]^{* * *}}\end{array}$ & & & $\begin{array}{l}0.277 \\
{[0.129]^{* *}}\end{array}$ \\
\hline Constant & $\begin{array}{l}2.289 \\
{[1.161]^{* *}}\end{array}$ & $\begin{array}{l}8.038 \\
{[0.519] * * *}\end{array}$ & $\begin{array}{l}7.175 \\
{[0.456]^{* * *}}\end{array}$ & $\begin{array}{l}4.924 \\
{[1.742] * * *}\end{array}$ & $\begin{array}{l}9.241 \\
{[0.495] * * *}\end{array}$ & $\begin{array}{l}8.694 \\
{[0.552]^{* * *}}\end{array}$ \\
\hline Observations & 88 & 88 & 86 & 88 & 88 & 86 \\
\hline Number of Banks & 15 & 15 & 15 & 15 & 15 & 15 \\
\hline
\end{tabular}

Notes: Standard errors in brackets

* significant at $10 \%$; * significant at $5 \%$; ** significant at $1 \%$ 
Table 4 International Banks

Panel Estimates (Random Effects Model)

\begin{tabular}{|c|c|c|c|c|c|c|}
\hline $\begin{array}{l}\text { Dependent Variable: } \\
\text { Loan Writeoff }\end{array}$ & 1 & 2 & 3 & 4 & 5 & 6 \\
\hline Profit(t-1), \% change & $\begin{array}{l}0.02 \\
{[0.028]}\end{array}$ & $\begin{array}{l}0.019 \\
{[0.026]}\end{array}$ & $\begin{array}{l}0.045 \\
{[0.049]}\end{array}$ & $\begin{array}{l}0.005 \\
{[0.029]}\end{array}$ & $\begin{array}{l}0.019 \\
{[0.026]}\end{array}$ & $\begin{array}{l}0.05 \\
{[0.050]}\end{array}$ \\
\hline GDP(t-1), \% change & $\begin{array}{l}0.028 \\
{[0.041]}\end{array}$ & $\begin{array}{l}0.03 \\
{[0.040]}\end{array}$ & $\begin{array}{l}0.018 \\
{[0.043]}\end{array}$ & $\begin{array}{l}0.029 \\
{[0.039]}\end{array}$ & $\begin{array}{l}0.041 \\
{[0.038]}\end{array}$ & $\begin{array}{l}0.036 \\
{[0.041]}\end{array}$ \\
\hline $\begin{array}{l}\text { Bad Loans }(t-1), \\
\% \text { change }\end{array}$ & $\begin{array}{l}0.00043 \\
{[0.00068]}\end{array}$ & $\begin{array}{l}0.00042 \\
{[0.00067]}\end{array}$ & $\begin{array}{l}0.00043 \\
{[0.00069]}\end{array}$ & $\begin{array}{l}0.00068 \\
{[0.00067]}\end{array}$ & $\begin{array}{l}0.00058 \\
{[0.00067]}\end{array}$ & $\begin{array}{l}0.00069 \\
{[0.00069]}\end{array}$ \\
\hline $\begin{array}{l}\text { Capital Injection } \\
\text { Dummy97(t-1) }\end{array}$ & $\begin{array}{l}0.313 \\
{[0.140]^{* *}}\end{array}$ & $\begin{array}{l}0.366 \\
{[0.147]^{* *}}\end{array}$ & $\begin{array}{l}0.352 \\
{[0.145]^{* *}}\end{array}$ & & & \\
\hline $\begin{array}{l}\text { Capital Injection } \\
\text { Dummy98(t-1) }\end{array}$ & $\begin{array}{l}-0.047 \\
{[0.229]}\end{array}$ & $\begin{array}{l}-0.05 \\
{[0.200]}\end{array}$ & $\begin{array}{l}-0.033 \\
{[0.211]}\end{array}$ & & & \\
\hline $\begin{array}{l}\text { Capital Injection97 } \\
\text { /Bank Assets(t-1) }\end{array}$ & & & & $\begin{array}{l}0.553 \\
{[0.230]^{* *}}\end{array}$ & $\begin{array}{l}0.448 \\
{[0.206]^{* *}}\end{array}$ & $\begin{array}{l}0.47 \\
{[0.209]^{* *}}\end{array}$ \\
\hline $\begin{array}{l}\text { Capital Injection98 } \\
\text { /Bank Assets(t-1) }\end{array}$ & & & & $\begin{array}{l}0.125 \\
{[0.111]}\end{array}$ & $\begin{array}{l}0.038 \\
{[0.088]}\end{array}$ & $\begin{array}{l}0.064 \\
{[0.094]}\end{array}$ \\
\hline $\begin{array}{l}\text { BIS/MOF } \\
\text { Capital Ratio(t-1) }\end{array}$ & $\begin{array}{l}0.018 \\
{[0.054]}\end{array}$ & & & $\begin{array}{l}-0.069 \\
{[0.066]}\end{array}$ & & \\
\hline $\begin{array}{l}\text { Total Capital / } \\
\text { Asset Ratio(t-1) }\end{array}$ & & $\begin{array}{l}0.041 \\
{[0.042]}\end{array}$ & & & $\begin{array}{l}0.012 \\
{[0.042]}\end{array}$ & \\
\hline $\begin{array}{l}\text { Core Capital } \\
\text { Ratio(t-1) }\end{array}$ & & & $\begin{array}{l}0.03 \\
{[0.047]}\end{array}$ & & & $\begin{array}{l}-0.011 \\
{[0.049]}\end{array}$ \\
\hline Constant & $\begin{array}{l}-0.225 \\
{[0.529]}\end{array}$ & $\begin{array}{l}-0.212 \\
{[0.186]}\end{array}$ & $\begin{array}{l}-0.168 \\
{[0.214]}\end{array}$ & $\begin{array}{l}0.594 \\
{[0.638]}\end{array}$ & $\begin{array}{l}-0.112 \\
{[0.175]}\end{array}$ & $\begin{array}{l}-0.02 \\
{[0.212]}\end{array}$ \\
\hline $\begin{array}{l}\text { Observations } \\
\text { Number of Banks }\end{array}$ & $\begin{array}{l}88 \\
15\end{array}$ & $\begin{array}{l}88 \\
15\end{array}$ & $\begin{array}{l}86 \\
15 \\
\end{array}$ & $\begin{array}{l}88 \\
15\end{array}$ & $\begin{array}{l}88 \\
15\end{array}$ & $\begin{array}{l}86 \\
15\end{array}$ \\
\hline
\end{tabular}

Notes: Standard errors in brackets

* significant at $10 \%$;* significant at 5\%; *** significant at $1 \%$ 
Table 5 International Banks

Panel Estimates (Random Effects Model)

\begin{tabular}{|c|c|c|c|c|c|c|}
\hline $\begin{array}{l}\text { Dependent Variable: } \\
\text { Total Loan Growth } \\
\end{array}$ & 1 & 2 & 3 & 4 & 5 & 6 \\
\hline Profit(t-1), \% change & $\begin{array}{l}-0.42 \\
{[0.458]}\end{array}$ & $\begin{array}{l}-0.323 \\
{[0.407]}\end{array}$ & $\begin{array}{l}-1.977 \\
{[0.719]^{* * *}}\end{array}$ & $\begin{array}{l}-0.29 \\
{[0.473]}\end{array}$ & $\begin{array}{l}-0.271 \\
{[0.412]}\end{array}$ & $\begin{array}{l}-1.886 \\
{[0.744]^{* *}}\end{array}$ \\
\hline GDP(t-1), \% change & $\begin{array}{l}0.222 \\
{[0.481]}\end{array}$ & $\begin{array}{l}0.344 \\
{[0.428]}\end{array}$ & $\begin{array}{l}0.114 \\
{[0.412]}\end{array}$ & $\begin{array}{l}0.481 \\
{[0.484]}\end{array}$ & $\begin{array}{l}0.478 \\
{[0.416]}\end{array}$ & $\begin{array}{l}0.278 \\
{[0.406]}\end{array}$ \\
\hline $\begin{array}{l}\text { Capital Injection } \\
\text { Dummy97(t-1) }\end{array}$ & $\begin{array}{l}-7.339 \\
{[2.309] * * *}\end{array}$ & $\begin{array}{l}-5.648 \\
{[2.382]^{* *}}\end{array}$ & $\begin{array}{l}-8.188 \\
{[2.163]^{* * *}}\end{array}$ & & & \\
\hline $\begin{array}{l}\text { Capital Injection } \\
\text { Dummy98(t-1) }\end{array}$ & $\begin{array}{l}-0.151 \\
{[3.193]}\end{array}$ & $\begin{array}{l}-1.402 \\
{[2.779]}\end{array}$ & $\begin{array}{l}-3.099 \\
{[2.612]}\end{array}$ & & & \\
\hline $\begin{array}{l}\text { Capital Injection97 } \\
\text { /Bank Assets(t-1) }\end{array}$ & & & & $\begin{array}{l}-7.526 \\
{[3.810]^{* *}}\end{array}$ & $\begin{array}{l}-5.442 \\
{[3.391]}\end{array}$ & $\begin{array}{l}-9.117 \\
{[3.205]^{* * *}}\end{array}$ \\
\hline $\begin{array}{l}\text { Capital Injection98 } \\
\text { /Bank Assets(t-1) }\end{array}$ & & & & $\begin{array}{l}0.422 \\
{[1.585]}\end{array}$ & $\begin{array}{l}-0.375 \\
{[1.250]}\end{array}$ & $\begin{array}{l}-1.002 \\
{[1.182]}\end{array}$ \\
\hline $\begin{array}{l}\text { BIS/MOF } \\
\text { Capital Ratio(t-1) }\end{array}$ & $\begin{array}{l}0 \\
{[0.834]}\end{array}$ & & & $\begin{array}{l}0.306 \\
{[1.006]}\end{array}$ & & \\
\hline $\begin{array}{l}\text { Total Capital / } \\
\text { Asset Ratio(t-1) }\end{array}$ & & $\begin{array}{l}1.309 \\
{[0.600]^{* *}}\end{array}$ & & & $\begin{array}{l}1.61 \\
{[0.602]^{* * *}}\end{array}$ & \\
\hline $\begin{array}{l}\text { Core Capital } \\
\text { Ratio(t-1) }\end{array}$ & & & $\begin{array}{l}1.098 \\
{[0.552]^{* *}}\end{array}$ & & & $\begin{array}{l}1.51 \\
{[0.573]^{* * *}}\end{array}$ \\
\hline Constant & $\begin{array}{l}0.048 \\
{[8.324]}\end{array}$ & $\begin{array}{l}-5.272 \\
{[2.700]^{*}}\end{array}$ & $\begin{array}{l}-4.253 \\
{[2.710]}\end{array}$ & $\begin{array}{l}-3.81 \\
{[9.886]}\end{array}$ & $\begin{array}{l}-7.022 \\
{[2.566]^{* * *}}\end{array}$ & $\begin{array}{l}-6.815 \\
{[2.680]^{* *}}\end{array}$ \\
\hline Observations & 120 & 120 & 118 & 120 & 120 & 118 \\
\hline Number of Banks & 15 & 15 & 15 & 15 & 15 & 15 \\
\hline
\end{tabular}

Notes: Standard errors in brackets

* significant at $10 \%$; * significant at $5 \%$; ** significant at $1 \%$ 
Table 6 International Banks

Panel Estimates (Random Effects Model)

\begin{tabular}{|c|c|c|c|c|c|c|}
\hline $\begin{array}{l}\text { Dependent Variable: } \\
\text { SME Loan Growth } \\
\end{array}$ & 1 & 2 & 3 & 4 & 5 & 6 \\
\hline Profit(t-1), \% change & $\begin{array}{l}0.208 \\
{[0.366]}\end{array}$ & $\begin{array}{l}0.697 \\
{[0.346]^{* *}}\end{array}$ & $\begin{array}{l}-1.002 \\
{[0.516]^{*}}\end{array}$ & $\begin{array}{l}0.138 \\
{[0.356]}\end{array}$ & $\begin{array}{l}0.668 \\
{[0.331]^{* *}}\end{array}$ & $\begin{array}{l}-1.065 \\
{[0.487]^{* *}}\end{array}$ \\
\hline GDP(t-1), \% change & $\begin{array}{l}0.232 \\
{[0.384]}\end{array}$ & $\begin{array}{l}0.741 \\
{[0.363]^{* *}}\end{array}$ & $\begin{array}{l}0.511 \\
{[0.295]^{*}}\end{array}$ & $\begin{array}{l}0.102 \\
{[0.364]}\end{array}$ & $\begin{array}{l}0.688 \\
{[0.334]^{* *}}\end{array}$ & $\begin{array}{l}0.513 \\
{[0.266]^{*}}\end{array}$ \\
\hline $\begin{array}{l}\text { Capital Injection } \\
\text { Dummy97(t-1) }\end{array}$ & $\begin{array}{l}-0.369 \\
{[1.844]}\end{array}$ & $\begin{array}{l}-1.95 \\
{[2.022]}\end{array}$ & $\begin{array}{l}-3.371 \\
{[1.553]^{* *}}\end{array}$ & & & \\
\hline $\begin{array}{l}\text { Capital Injection } \\
\text { Dummy98(t-1) }\end{array}$ & $\begin{array}{l}12.065 \\
{[2.550]^{* * *}}\end{array}$ & $\begin{array}{l}8.405 \\
{[2.359]^{* * *}}\end{array}$ & $\begin{array}{l}5.295 \\
{[1.875]^{* * *}}\end{array}$ & & & \\
\hline $\begin{array}{l}\text { Capital Injection97 } \\
\text { /Bank Assets(t-1) }\end{array}$ & & & & $\begin{array}{l}-2.165 \\
{[2.864]}\end{array}$ & $\begin{array}{l}-7.775 \\
{[2.723]^{* * *}}\end{array}$ & $\begin{array}{l}-8.915 \\
{[2.099]^{* * *}}\end{array}$ \\
\hline $\begin{array}{l}\text { Capital Injection98 } \\
\text { /Bank Assets(t-1) }\end{array}$ & & & & $\begin{array}{l}6.164 \\
{[1.191]^{* * *}}\end{array}$ & $\begin{array}{l}4.067 \\
{[1.004]^{* * *}}\end{array}$ & $\begin{array}{l}2.502 \\
{[0.774]^{* * *}}\end{array}$ \\
\hline $\begin{array}{l}\text { BIS/MOF } \\
\text { Capital Ratio(t-1) }\end{array}$ & $\begin{array}{l}-2.31 \\
{[0.666]^{* * *}}\end{array}$ & & & $\begin{array}{l}-2.8 \\
{[0.756]^{* * *}}\end{array}$ & & \\
\hline $\begin{array}{l}\text { Total Capital / } \\
\text { Asset Ratio(t-1) }\end{array}$ & & $\begin{array}{l}-0.746 \\
{[0.510]}\end{array}$ & & & $\begin{array}{l}-1.067 \\
{[0.483]^{* *}}\end{array}$ & \\
\hline $\begin{array}{l}\text { Core Capital } \\
\text { Ratio(t-1) }\end{array}$ & & & $\begin{array}{l}-0.799 \\
{[0.396]^{* *}}\end{array}$ & & & $\begin{array}{l}-0.768 \\
{[0.375]^{* *}}\end{array}$ \\
\hline Constant & $\begin{array}{l}19.443 \\
{[6.647]^{* * *}}\end{array}$ & $\begin{array}{l}-0.336 \\
{[2.292]}\end{array}$ & $\begin{array}{l}1.171 \\
{[1.946]}\end{array}$ & $\begin{array}{l}24.378 \\
{[7.432]^{* * *}}\end{array}$ & $\begin{array}{l}1.143 \\
{[2.061]}\end{array}$ & $\begin{array}{l}1.104 \\
{[1.755]}\end{array}$ \\
\hline $\begin{array}{l}\text { Observations } \\
\text { Number of Banks }\end{array}$ & $\begin{array}{l}120 \\
15 \\
\end{array}$ & $\begin{array}{l}120 \\
15\end{array}$ & $\begin{array}{l}118 \\
15 \\
\end{array}$ & $\begin{array}{l}120 \\
15 \\
\end{array}$ & $\begin{array}{l}120 \\
15 \\
\end{array}$ & $\begin{array}{l}118 \\
15 \\
\end{array}$ \\
\hline
\end{tabular}

Notes: Standard errors in brackets

* significant at $10 \%$; * significant at $5 \%$; ** significant at $1 \%$ 
Table 7 Regional Banks

Panel Estimates (Random Effects Model)

\begin{tabular}{|c|c|c|c|c|}
\hline $\begin{array}{l}\text { Dependent Variable: } \\
\text { MOF Capital Ratio }\end{array}$ & 1 & 2 & 3 & 4 \\
\hline Profit(t-1), \% change & $\begin{array}{l}-0.059 \\
{[0.059]}\end{array}$ & $\begin{array}{l}0.068 \\
{[0.065]}\end{array}$ & $\begin{array}{l}-0.056 \\
{[0.058]}\end{array}$ & $\begin{array}{l}0.073 \\
{[0.064]}\end{array}$ \\
\hline GDP(t-1), \% change & $\begin{array}{l}-0.017 \\
{[0.021]}\end{array}$ & $\begin{array}{l}-0.089 \\
{[0.024]^{* * *}}\end{array}$ & $\begin{array}{l}-0.016 \\
{[0.021]}\end{array}$ & $\begin{array}{l}-0.089 \\
{[0.024]^{* * *}}\end{array}$ \\
\hline $\begin{array}{l}\text { Bad Loans }(t-1), \\
\% \text { change }\end{array}$ & $\begin{array}{l}-0.00043 \\
{[0.00050]}\end{array}$ & $\begin{array}{l}-0.00011 \\
{[0.00057]}\end{array}$ & $\begin{array}{l}-0.00045 \\
{[0.00050]}\end{array}$ & $\begin{array}{l}-0.00013 \\
{[0.00056]}\end{array}$ \\
\hline $\begin{array}{l}\text { Capital Injection } \\
\text { Dummy97(t-1) }\end{array}$ & $\begin{array}{l}-3.209 \\
{[0.738] * * *}\end{array}$ & $\begin{array}{l}-2.174 \\
{[0.850]^{* *}}\end{array}$ & & \\
\hline $\begin{array}{l}\text { Capital Injection } \\
\text { Dummy99(t-1) }\end{array}$ & $\begin{array}{l}0.91 \\
{[0.432]^{* *}}\end{array}$ & $\begin{array}{l}1.133 \\
{[0.497]^{* *}}\end{array}$ & & \\
\hline $\begin{array}{l}\text { Capital Injection97 / } \\
\text { Bank Assets(t-1) }\end{array}$ & & & $\begin{array}{l}-8.347 \\
{[1.764]^{* * *}}\end{array}$ & $\begin{array}{l}-5.959 \\
{[2.033] * * *}\end{array}$ \\
\hline $\begin{array}{l}\text { Capital Injection99 / } \\
\text { Bank Assets(t-1) }\end{array}$ & & & $\begin{array}{l}0.542 \\
{[0.216]^{* *}}\end{array}$ & $\begin{array}{l}0.599 \\
{[0.249]^{* *}}\end{array}$ \\
\hline $\begin{array}{l}\text { BIS/MOF } \\
\text { Capital Ratio(t-1) }\end{array}$ & $\begin{array}{l}0.853 \\
{[0.017]^{* * *}}\end{array}$ & & $\begin{array}{l}0.854 \\
{[0.017]^{* * *}}\end{array}$ & \\
\hline $\begin{array}{l}\text { Total Capital / } \\
\text { Asset Ratio(t-1) }\end{array}$ & & $\begin{array}{l}0.759 \\
{[0.061]^{* * *}}\end{array}$ & & $\begin{array}{l}0.757 \\
{[0.061]^{* * *}}\end{array}$ \\
\hline Constant & $\begin{array}{l}1.366 \\
{[0.153]^{* * *}}\end{array}$ & $\begin{array}{l}5.486 \\
{[0.292]^{* * *}}\end{array}$ & $\begin{array}{l}1.362 \\
{[0.152]^{* * *}}\end{array}$ & $\begin{array}{l}5.497 \\
{[0.292]^{* * *}}\end{array}$ \\
\hline $\begin{array}{l}\text { Observations } \\
\text { Number of Banks }\end{array}$ & $\begin{array}{l}714 \\
91\end{array}$ & $\begin{array}{l}714 \\
91\end{array}$ & $\begin{array}{l}714 \\
91\end{array}$ & $\begin{array}{l}714 \\
91\end{array}$ \\
\hline
\end{tabular}

Notes: Standard errors in brackets

* significant at $10 \%$; * significant at $5 \%$; ** significant at $1 \%$ 
Table 8 Regional Banks

Panel Estimates (Random Effects Model)

\begin{tabular}{|c|c|c|c|c|}
\hline $\begin{array}{l}\text { Dependent Variable: } \\
\text { Loan Write Offs (as } \\
\text { ratio to total assets) }\end{array}$ & 1 & 2 & 3 & 4 \\
\hline Profit(t-1), \% change & $\begin{array}{l}0.061 \\
{[0.011]^{* * *}}\end{array}$ & $\begin{array}{l}0.062 \\
{[0.011]^{* * *}}\end{array}$ & $\begin{array}{l}0.061 \\
{[0.010]^{* * *}}\end{array}$ & $\begin{array}{l}0.062 \\
{[0.011]^{* * *}}\end{array}$ \\
\hline GDP(t-1), \% change & $\begin{array}{l}-0.005 \\
{[0.004]}\end{array}$ & $\begin{array}{l}-0.005 \\
{[0.004]}\end{array}$ & $\begin{array}{l}-0.005 \\
{[0.004]}\end{array}$ & $\begin{array}{l}-0.005 \\
{[0.004]}\end{array}$ \\
\hline $\begin{array}{l}\text { Bad Loans }(t-1), \\
\% \text { change }\end{array}$ & $\begin{array}{l}0.00024 \\
{[0.00009]^{* * *}}\end{array}$ & $\begin{array}{l}0.00024 \\
{[0.00009]^{* * *}}\end{array}$ & $\begin{array}{l}0.00024 \\
{[0.00009]^{* * *}}\end{array}$ & $\begin{array}{l}0.00024 \\
{[0.00009]^{* * *}}\end{array}$ \\
\hline $\begin{array}{l}\text { Capital Injection } \\
\text { Dummy97(t-1) }\end{array}$ & $\begin{array}{l}-0.203 \\
{[0.130]}\end{array}$ & $\begin{array}{l}-0.202 \\
{[0.130]}\end{array}$ & & \\
\hline $\begin{array}{l}\text { Capital Injection } \\
\text { Dummy99(t-1) }\end{array}$ & $\begin{array}{l}0.022 \\
{[0.076]}\end{array}$ & $\begin{array}{l}0.02 \\
{[0.076]}\end{array}$ & & \\
\hline $\begin{array}{l}\text { Capital Injection97 } \\
\text { /Bank Assets(t-1) }\end{array}$ & & & $\begin{array}{l}-0.699 \\
{[0.311]^{* *}}\end{array}$ & $\begin{array}{l}-0.698 \\
{[0.312]^{* *}}\end{array}$ \\
\hline $\begin{array}{l}\text { Capital Injection99 } \\
\text { /Bank Assets(t-1) }\end{array}$ & & & $\begin{array}{l}-0.005 \\
{[0.038]}\end{array}$ & $\begin{array}{l}-0.006 \\
{[0.038]}\end{array}$ \\
\hline $\begin{array}{l}\text { BIS/MOF } \\
\text { Capital Ratio(t-1) }\end{array}$ & $\begin{array}{l}0.002 \\
{[0.003]}\end{array}$ & & $\begin{array}{l}0.002 \\
{[0.003]}\end{array}$ & \\
\hline $\begin{array}{l}\text { Total Capital / } \\
\text { Asset Ratio(t-1) }\end{array}$ & & $\begin{array}{l}0 \\
{[0.007]}\end{array}$ & & $\begin{array}{l}-0.001 \\
{[0.007]}\end{array}$ \\
\hline Constant & $\begin{array}{l}0.001 \\
{[0.027]}\end{array}$ & $\begin{array}{l}0.017 \\
{[0.031]}\end{array}$ & $\begin{array}{l}0.002 \\
{[0.027]}\end{array}$ & $\begin{array}{l}0.02 \\
{[0.031]}\end{array}$ \\
\hline $\begin{array}{l}\text { Observations } \\
\text { Number of Banks }\end{array}$ & $\begin{array}{l}679 \\
91\end{array}$ & $\begin{array}{l}679 \\
91\end{array}$ & $\begin{array}{l}679 \\
91\end{array}$ & $\begin{array}{l}679 \\
91\end{array}$ \\
\hline
\end{tabular}

Notes: Standard errors in brackets

* significant at $10 \%$; * significant at 5\%; *** significant at $1 \%$ 
Table 9 Regional Banks

Panel Estimates (Random Effects Model)

\begin{tabular}{|c|c|c|c|c|}
\hline $\begin{array}{l}\text { Dependent Variable: Total } \\
\text { Loan Growth }\end{array}$ & 1 & 2 & 3 & 4 \\
\hline Profit(t-1), \% change & $\begin{array}{l}0.838 \\
{[0.276] * * *}\end{array}$ & $\begin{array}{l}0.851 \\
{[0.278] * * *}\end{array}$ & $\begin{array}{l}0.831 \\
{[0.275]^{* * *}}\end{array}$ & $\begin{array}{l}0.843 \\
{[0.277]^{* * *}}\end{array}$ \\
\hline GDP(t-1), \% change & $\begin{array}{l}0.464 \\
{[0.074] * * *}\end{array}$ & $\begin{array}{l}0.47 \\
{[0.074]^{* * *}}\end{array}$ & $\begin{array}{l}0.465 \\
{[0.074]^{* * *}}\end{array}$ & $\begin{array}{l}0.471 \\
{[0.074]^{* * *}}\end{array}$ \\
\hline $\begin{array}{l}\text { Capital Injection } \\
\text { Dummy97(t-1) }\end{array}$ & $\begin{array}{l}-1.058 \\
{[4.064]}\end{array}$ & $\begin{array}{l}-1.58 \\
{[4.077]}\end{array}$ & & \\
\hline $\begin{array}{l}\text { Capital Injection } \\
\text { Dummy99(t-1) }\end{array}$ & $\begin{array}{l}-1.303 \\
{[2.371]}\end{array}$ & $\begin{array}{l}-1.294 \\
{[2.372]}\end{array}$ & & \\
\hline $\begin{array}{l}\text { Capital Injection97 / } \\
\text { Bank Assets(t-1) }\end{array}$ & & & $\begin{array}{l}-1.389 \\
{[9.756]}\end{array}$ & $\begin{array}{l}-2.617 \\
{[9.786]}\end{array}$ \\
\hline $\begin{array}{l}\text { Capital Injection99 / } \\
\text { Bank Assets(t-1) }\end{array}$ & & & $\begin{array}{l}-0.544 \\
{[1.191]}\end{array}$ & $\begin{array}{l}-0.518 \\
{[1.192]}\end{array}$ \\
\hline $\begin{array}{l}\text { BIS/MOF } \\
\text { Capital Ratio(t-1) }\end{array}$ & $\begin{array}{l}-0.122 \\
{[0.091]}\end{array}$ & & $\begin{array}{l}-0.122 \\
{[0.091]}\end{array}$ & \\
\hline $\begin{array}{l}\text { Total Capital / } \\
\text { Asset Ratio(t-1) }\end{array}$ & & $\begin{array}{l}-0.213 \\
{[0.199]}\end{array}$ & & $\begin{array}{l}-0.211 \\
{[0.199]}\end{array}$ \\
\hline Constant & $\begin{array}{l}1.939 \\
{[0.803]^{* *}}\end{array}$ & $\begin{array}{l}1.79 \\
{[0.858]^{* *}}\end{array}$ & $\begin{array}{l}1.935 \\
{[0.804]^{* *}}\end{array}$ & $\begin{array}{l}1.776 \\
{[0.858]^{* *}}\end{array}$ \\
\hline $\begin{array}{l}\text { Observations } \\
\text { Number of Banks }\end{array}$ & $\begin{array}{l}991 \\
91\end{array}$ & $\begin{array}{l}993 \\
91\end{array}$ & $\begin{array}{l}991 \\
91\end{array}$ & $\begin{array}{l}993 \\
91\end{array}$ \\
\hline
\end{tabular}

Notes: Standard errors in brackets

* significant at $10 \%$; * significant at $5 \%$; ** significant at $1 \%$ 
Table 10 Regional Banks

Panel Estimates (Random Effects Model)

\begin{tabular}{|c|c|c|c|c|}
\hline $\begin{array}{l}\text { Dependent Variable: } \\
\text { SME Loan Growth } \\
\end{array}$ & 1 & 2 & 3 & 4 \\
\hline Profit(t-1), \% change & $\begin{array}{l}0.568 \\
{[0.263]^{* *}}\end{array}$ & $\begin{array}{l}0.576 \\
{[0.266]^{* *}}\end{array}$ & $\begin{array}{l}0.557 \\
{[0.262]^{* *}}\end{array}$ & $\begin{array}{l}0.565 \\
{[0.264]^{* *}}\end{array}$ \\
\hline GDP(t-1), \% change & $\begin{array}{l}0.198 \\
{[0.071] * * *}\end{array}$ & $\begin{array}{l}0.21 \\
{[0.071] * * *}\end{array}$ & $\begin{array}{l}0.199 \\
{[0.071]^{* * *}}\end{array}$ & $\begin{array}{l}0.211 \\
{[0.071] * * *}\end{array}$ \\
\hline $\begin{array}{l}\text { Capital Injection } \\
\text { Dummy97(t-1) }\end{array}$ & $\begin{array}{l}0.39 \\
{[3.883]}\end{array}$ & $\begin{array}{l}-0.146 \\
{[3.904]}\end{array}$ & & \\
\hline $\begin{array}{l}\text { Capital Injection } \\
\text { Dummy99(t-1) }\end{array}$ & $\begin{array}{l}-1.87 \\
{[2.265]}\end{array}$ & $\begin{array}{l}-1.75 \\
{[2.272]}\end{array}$ & & \\
\hline $\begin{array}{l}\text { Capital Injection97 } \\
\text { /Bank Assets(t-1) }\end{array}$ & & & $\begin{array}{l}0.839 \\
{[9.321]}\end{array}$ & $\begin{array}{l}-0.451 \\
{[9.370]}\end{array}$ \\
\hline $\begin{array}{l}\text { Capital Injection99 } \\
\text { /Bank Assets(t-1) }\end{array}$ & & & $\begin{array}{l}-0.865 \\
{[1.138]}\end{array}$ & $\begin{array}{l}-0.788 \\
{[1.141]}\end{array}$ \\
\hline $\begin{array}{l}\text { BIS/MOF } \\
\text { Capital Ratio(t-1) }\end{array}$ & $\begin{array}{l}-0.194 \\
{[0.091]^{* *}}\end{array}$ & & $\begin{array}{l}-0.195 \\
{[0.091]^{* *}}\end{array}$ & \\
\hline $\begin{array}{l}\text { Total Capital / } \\
\text { Asset Ratio(t-1) }\end{array}$ & & $\begin{array}{l}-0.339 \\
{[0.196]^{*}}\end{array}$ & & $\begin{array}{l}-0.338 \\
{[0.196]^{*}}\end{array}$ \\
\hline Constant & $\begin{array}{l}2.33 \\
{[0.809]^{* * *}}\end{array}$ & $\begin{array}{l}2.071 \\
{[0.850]^{* *}}\end{array}$ & $\begin{array}{l}2.329 \\
{[0.809]^{* * *}}\end{array}$ & $\begin{array}{l}2.067 \\
{[0.849]^{* *}}\end{array}$ \\
\hline $\begin{array}{l}\text { Observations } \\
\text { Number of Banks }\end{array}$ & $\begin{array}{l}991 \\
91\end{array}$ & $\begin{array}{l}993 \\
91\end{array}$ & $\begin{array}{l}991 \\
91\end{array}$ & $\begin{array}{l}993 \\
91\end{array}$ \\
\hline
\end{tabular}

Notes: Standard errors in brackets

* significant at $10 \%$; * significant at 5\%; *** significant at $1 \%$ 


\section{Appendix 1: Banks Included in the Analysis}

\begin{tabular}{|c|c|c|}
\hline Regional Banks & Hokkoku & Tohoku \\
\hline FY1990 - FY2002 & Hokuetsu & Tokushima \\
\hline 77 & Hokuriku & Tokyo Tomin \\
\hline Aichi & Howa & Tomato \\
\hline Akita & Hyakugo & Towa \\
\hline Aomori & Hyakujushi & Toyama \\
\hline Ashikaga & Iyo & Yamagata \\
\hline Awa & Joyo & Yamaguchi \\
\hline Bank of Fukuoka & Juroku & Yamanashi Chuo \\
\hline Bank of Ikeda & Kagawa & \\
\hline Bank of Iwate & Kagoshima & International Banks \\
\hline Bank of Kansai & Kanto & FY1990 - FY1999 \\
\hline Bank of Kinki ${ }^{19}$ & Keiyo & Asahi \\
\hline Bank of Kyoto & Kita Nippon & Bank of Tokyo \\
\hline Bank of Nagoya & Kiyo & Mitsubishi \\
\hline Bank of Okinawa & Kumamoto Family & Daiichi Kangyo \\
\hline Bank of Saga & Kyushu & Daiwa \\
\hline Bank of the Ryukyus & Michinoku & Fuji \\
\hline Biwako & Mie & Industrial Bank of Japan \\
\hline Chiba & Minami-Nippon & Mitsubishi Trust \\
\hline Chiba Kogyo & Miyazaki & Mitsui Trust \\
\hline Chikuho & Miyazaki-Taiyo & Nippon Trust \\
\hline Chugoku & Musashino & Sakura \\
\hline Chukyo & Nagano & Sanwa \\
\hline Daisan & Nanto & Sumitomo Trust \\
\hline Daishi & Nishi-Nippon & Tokai \\
\hline Daito & North Pacific & Toyo Trust \\
\hline Ehime & Ogaki Kyoritsu & Yasuda Trust \\
\hline EighteenthBank & Oita & \\
\hline Fukui & San-in Godo & \\
\hline Fukuoka Chuo & Sapporo & \\
\hline Fukuoka City & Senshu & \\
\hline Fukushima & Setouchi & \\
\hline Gifu & Shiga & \\
\hline Gunma & Shikoku & \\
\hline Hachijuni & Shimizu & \\
\hline Higashi-Nippon & Shinwa & \\
\hline Higo & Shizuoka & \\
\hline Hiroshima & Shokusan & \\
\hline Hiroshima Sogo & Suruga & \\
\hline \multirow[t]{2}{*}{ Hokkaido } & Taiko & \\
\hline & Tochigi & \\
\hline $\begin{array}{l}{ }^{19} \text { Bank of Kinki data } \\
\text { available through FY19 }\end{array}$ & Toho & \\
\hline
\end{tabular}


The following banks are excluded from the analysis because they were closed or nationalized during the sample period between FY1982-FY1999. Hokkaido Takushoku Bank failed on October 17, 1997. The Nippon Credit Bank ${ }^{20}$ was nationalized on December 13, 1998 and in January 2001 reopened as Aozora Bank. The Long Term Credit Bank of Japan was nationalized on October 23, 1998 and reopened on June 5, 2000 as Shinsei Bank. Namihaya Bank, which was formed on October 1, 1998 from the merger of Bank of Naniwa and Fukutoku Bank, was closed on August 6, $1999^{21}$ Hanwa Bank failed in November 1996. Kofuku Bank, which absorbed Kyoto Kyoei Bank on October 26, 1998, closed on May 21, 1999. Kokumin Bank ${ }^{22}$ failed on April 11, 1999, and was absorbed by Yachiyo Bank ${ }^{23}$ on August 14, 2000. Minato Bank ${ }^{24}$ was established toward the end of the sample on September 1, 1999. Niigata-Chuo Bank ${ }^{25}$ failed in October 1999. Tokuyo City Bank failed on November 26, 1997, and was absorbed by Sendai Bank ${ }^{26}$ on November 24, 1998. Tokyo Sowa Bank, established in 1950 as a "sogo" bank ${ }^{27}$, was closed on June 11, 1999. In addition, Hokuto Bank is excluded because it was established mid-sample in 1993. The Bank was first established in 1895 as Masuda Bank and changed its name to Hokuto Bank after absorbing Akita Akebono Bank on April 1, 1993.

Data for Asahi Bank ${ }^{28}$, which was formed by the merger of Kyowa Bank and Saitama Bank on April 1, 1991, is backdated by combining data from the two bank balance sheets. The same technique is used to backdate data for Tokyo-Mitsubishi Bank, which was formed by the merger of Bank of Tokyo Bank and Mistubishi Bank on April 1, 1996 and for Sakura Bank, which was established on April 1990 through the merger of Mitsui Bank Ltd. and Taiyo Kobe Bank Ltd. In order to include Sendai Bank in the sample, the last fiscal year of data is not used.

Several other banks in the sample - Dai-Ichi Kangyo Bank, Joyo Bank, MinamiNippon Bank and Tokai Bank were also formed as the result of mergers, although they occurred before the sample period so no data adjustment was necessary. Dai-Ichi Kangyo was established on October 1, 1971 (pre-sample) through the merger of the Dai-Ichi Bank Ltd. and The Nippon Kangyo Bank Ltd. Joyo Bank Ltd. was established on July 30, 1935 following merger of Tokiwa Bank and Goyu Bank. Tokai Bank was established in 1941 as the result of the merger between Aichi Bank, Nagoya Bank and Ito Bank. MinamiNippon Bank, a domestic bank, was established in 1943 through the merger of 2 local banking institutes in Kagoshima prefecture.

\footnotetext{
${ }^{20}$ Established on April 1, 1957 as Hypotec Bank of Japan, Ltd. In 1970, its name changed to Nippon Fudosan Bank and to Nippon Credit Bank Ltd in 1977.

${ }^{21}$ In February 2001 the failed Namihaya Bank was absorbed by Daiwa Bank and Kinki Osaka Bank.

${ }^{22}$ The bank was established in 1926 as Kofuku Sogo Bank Ltd. In February 1, 1989, upon converting to a regional II bank, its name changed to Kofuku Bank, Ltd. After being closed, Kofuku Bank was purchased by the Asia Recovery Fund and reopened on February 26, 2001 as Kansai Sawayaka Bank, Ltd.

${ }^{23}$ Yachiyo was originally established in 1924 as Credit Union. In 1991, its name changed to Yachiyo Bank.

${ }^{24}$ Minato Bank was formed from the merger of Midori Bank and Hanshin Bank on April 1, 1999.

${ }^{25}$ Niigata Chuo was eventually absorbed by six other regional banks: Higashi-Nippon, Gunma Bank, Towa

Bank, Taiko Bank, Daishi Bank and Hyakujushi Bank.

${ }^{26}$ Sendai Bank was originally established on July 5, 1951.

${ }^{27}$ Tokyo Sogo Bank converted to a regional II bank in 1989 and its name changed to Tokyo Sowa Bank.

${ }^{28}$ The merged bank was first named the Kyowa Saitama Bank. The bank name was changed to Asahi Bank on September 21, 1992.
} 
Recent mergers forming the Mizuho Financial Group (a holding company of DaiIchi Kangyo Bank, Fuji Bank and Industrial Bank of Japan), the Sumitomo Mitsui Banking Corporation (formed by the merger of Sumitomo Bank and Sakura Bank in April 2001), Chuo Mitsui Trust Bank (formed by the merger of Chuo Trust and Mitsui Trust in April 2000), and the Mitsubishi Tokyo Financial Group (formed in April 2001 by Tokyo Mitsubishi Bank and Mitsubishi Trust; soon to be joined by Nippon Trust and Toyo Trust) occurred post-sample and thus do not require any data adjustments. 


\section{Appendix 2: Japanese Bankers Association - Risk Management Loans}

Risk management loans as defined by the Japanese Bankers Association have been reported by individual banks since fiscal year 1993. The categories used by the JBA include:

a. Restructured loans: The least dangerous category of loans, restructured loans were originally defined only as loans for which the interest rate had been lowered, but in fiscal year 1997 the definition was expanded to include loans for which any contract condition has been amended and loans to corporations undergoing reorganization. Restructured loans were reported by the largest banks beginning in 1994 and reporting requirements were extended to regional banks in 1996.

b. 3 Month Overdue Loans: 3 month overdue loans, or 3PDL (3 month past due loans), are defined as loans in arrears by more than 3 months but less than 6 months. Overdue loans originally included loans on which interest payments are past due by more than six months (see below), but in fiscal year 1997 this stricter category of overdue loans, loans on which interest payments are past-due by more than 90 days, was added. Reporting of 3 month overdue loans has been required of all banks only since fiscal year 1998.

c. Overdue loans: Overdue loans, or PDL (Past Due Loans), are loans on which interest payments are past due by more than 6 months. These loans have been reported by the largest banks since 1993, but the regional banks only began reporting this category of loans in 1996.

d. Defaulted loans: Defaluted loans, or LBB (Loans to Borrowers in Legal Bankruptcy), carry the strictest definition. These are loans to companies in the legal process of declaring bankruptcy. This category of loans has been reported by all banks (City, Trust, Long-Term Credit and Regional) since fiscal year 1993. In March 1999, the definition of defaulted loans was expanded to include loans for which principal or interest payments have not been made in a "long time" and for which repayment is judged "unlikely". 


\section{$\underline{\text { Endnotes }}$}

i The Financial Revitalization Plan also legislated the merger of the Resolution and Collection Bank (RCB), which had been overseeing the liquidation of the assets of failed credit cooperatives, with the Housing Loan Administration Corporation (HLAC), which had been dealing with the remaining bad assets of the jusens, into the Resolution and Collection Corporation (RCC), a public asset management company. Details on this merger are available in figure 33. The RCC had an expanded mandate allowing it to purchase bad loans from solvent financial institutions as well as failed banks.

Under the Financial Revitalization Plan, the Financial Revitalization Commission (FRC) was established under Prime Ministers Office to oversee bank restructuring.

Restructuring followed one of two courses: the bridge bank scheme or nationalization. Under the bridge bank scheme, the troubled bank was to be operated by public administrators as a bridge bank until a successor bank could be found. This system was used in closing smaller banks such as the Koufuku Bank, Kokumin Bank, Tokyo Sowa Bank and Namihaya Bank, all of which went into bankruptcy in 1999. The nationalization scheme was used for larger bank failures, such as the Long Term Credit Bank of Japan and Nippon Credit. In these cases, the banks were temporarily nationalized, with the DIC purchasing all shares and operating the bank until it was ready to resume business as a new bank. The FRC was due to complete its task by 2001 and closed on January 6, 2001.

${ }^{i i}$ DKB, Fuji Bank, IBJ and Yasuda Trust formed a holding company in September 2000 and merged into the Mizuho Financial Group in January 2003, which with assets of 14 billion Yen, is now the world's largest financial institution. The Sumitomo-Mitsui Financial Group, formed by the merger of Sumitomo Bank and Sakura Bank in April 2001, is now the world's second largest bank in terms of assets. This merger is of particular interest because the two main banks represent different keiretsu groups (the Sumitomo and Mitsui keiretsu). The world's third largest financial institution will also be a Japanese institution. Mitsubishi-Tokyo Financial Group (MTFG) was established in April 2001 by TokyoMitsubishi Bank and the merger of three trust banks: Mitsubishi, Nippon and Tokyo Trust October of the same year. The UFJ Group formed a holding company in April 2001 and merged Sanwa, Tokai and Toyo Trust in April 2002. Daiwa and Asahi has also merged into Resona Bank in March of 2003, but Resona has since then failed.

iii Until fiscal year 2001 when the accounting standards were strengthened, land holdings were recorded at book value on the balance sheet and banks were able to choose between the book value or fair value (lower of book or market) method for recording the value investment account equity holdings on their balance sheets. Banks that chose the fair value method could count $45 \%$ of unrealized gains toward Tier 2 Capital. 